\title{
Detection and genetic analysis of the enteroaggregative Escherichia coli heat-stable enterotoxin (EAST1) gene in clinical isolates of enteropathogenic Escherichia coli (EPEC) strains
}

\author{
Lucas EP Silva', Tamara B Souza ${ }^{1}$, Neusa P Silva ${ }^{2}$ and Isabel CA Scaletsky ${ }^{1 *}$
}

\begin{abstract}
Background: The enteroaggregative E. coli heat-stable enterotoxin 1 (EAST1) encoded by astA gene has been found in enteropathogenic E. coli (EPEC) strains. However, it is not sufficient to simply probe strains with an astA gene probe due to the existence of astA mutants (type 1 and type 2 SHEAST) and EAST1 variants (EAST1 v1-4). In this study, 222 EPEC (70 typical and 152 atypical) isolates were tested for the presence of the astA gene sequence by PCR and sequencing.

Results: The astA gene was amplified from 54 strains, 11 typical and 43 atypical. Sequence analysis of the PCR products showed that 25 strains, 7 typical and 18 atypical, had an intact astA gene. A subgroup of 7 atypical strains had a variant type of the astA gene sequence, with four non-synonymous nucleotide substitutions. The remaining 22 strains had mutated astA gene with nucleotide deletions or substitutions in the first 8 codons. The RT-PCR results showed that the astA gene was transcribed only by the strains carrying either the intact or the variant type of the astA gene sequence. Southern blot analysis indicated that astA is located in EAF plasmid in typical strains, and in plasmids of similar size in atypical strains. Strains carrying intact ast $A$ genes were more frequently found in diarrheic children than in non-diarrheic children $(p<0.05)$.
\end{abstract}

Conclusion: In conclusion, our data suggest that the presence of an intact astA gene may represent an additional virulence determinant in both EPEC groups.

Keywords: EAST1 gene, astA gene, Enteropathogenic Escherichia coli

\section{Background}

Enteropathogenic Escherichia coli (EPEC) are an important cause of infant diarrhea in developing countries [1]. The majority of EPEC isolates belong to classic serotypes derived from 12 classical O serogroups (O26, O55, O86, O111, O114, O119, O125, O126, O127, O128, O142, and O158) [2,3]. EPEC induces attaching and effacing (A/E) lesions on epithelial cells, characterized by microvilli destruction, cytoskeleton rearrangement, and the formation of a pedestal-like structure at the site of bacterial contact [4]. The $\mathrm{A} / \mathrm{E}$ genes are localized to the locus

\footnotetext{
* Correspondence: scaletskyunifesp@gmail.com

${ }^{1}$ Departamento de Microbiologia, Imunologia e Parasitologia, Universidade Federal de São Paulo, Rua Botucatu, 862, 3 andar, 04023-062 São Paulo, Brazil Full list of author information is available at the end of the article
}

for enterocyte effacement (LEE) and encode intimin, a type III secretion system, secreted proteins and the translocated intimin receptor [5-7].

"Typical" EPEC strains (tEPEC) contain also the EPEC adherence factor (EAF) plasmid [8], which carries genes encoding a regulator (per) [9] and the bundle-forming pili (BFP) [10]. EPEC strains lacking the EAF plasmid have been designated "atypical" EPEC (aEPEC) [11]. Recent epidemiological studies indicate that aEPEC are more prevalent than $\mathrm{EEPEC}$ in both developed and developing countries [1]. Some aEPEC strains are genetically related to the enterohemorrhagic E. coli (EHEC), and both are considered as emerging pathogens [12].

Typical EPEC strains express only the virulence factors encoded by the LEE region and the EAF plasmid, with 
the exception of the cytolethal distending toxin produced by O86:H34 strains and the enteroaggregative heat-stable enterotoxin 1 (EAST1) found in O55:H6 and O127:H6 strains. In contrast, aEPEC strains frequently express EAST1 and additional virulence factors not encoded by LEE region [12]. In a previous study [13], EAST1 was the most frequent (24\%) virulence factor found in a collection of 65 aEPEC strains, and was significantly associated with children diarrhea.

EAST1-positive aEPEC strains have been associated with outbreaks of diarrhea involving children and adults in the United State [14] and Japan [15]. However, it is not sufficient to simply probe strains with an astA gene probe due to the existence of EAST1 variants [16]. In one study, 100\% of the O26, O111, O145, and O157:H7 enterohemorrhagic E. coli (EHEC) strains examined carried DNA sequences homologous to the EAST1 gene (SHEAST) with two different mutation types. Type 1 SHEAST has 12 nucleotide non-synonymous substitutions including one in the initiation codon; type 2 SHEAST lacks the first 8 codons of EAST1 sequence [16]. The focus of the study was to investigate the ast $A$ gene sequence present in tEPEC and aEPEC strains. The strains were collected in different cities of Brazil in different periods of time and in a previous study poor relatedness was observed by RAPD analysis of 118 strains belonging to this collection [13].

\section{Results and discussion}

We examined 222 EPEC strains (70 typical and 152 atypical) for the presence of the astA gene by PCR using primers that anneal to the 5' ends of the EAEC 042 astA gene sequence [16]. Those strains were isolated from diarrheic and non diarrheic Brazilian children in previous studies [17-20]. As shown in Table 1, 11 (16\%) tEPEC and $43(28 \%)$ aEPEC strains were positive in the PCR assay. Among the aEPEC PCR-positive strains, 13 belonged to the $\mathrm{O} 26$ and $\mathrm{O} 119$ serogroups.

The 54 astA gene PCR products were sequenced. Twenty five strains, 7 tEPEC and 18 aEPEC, carried the DNA sequence identical to the EAST1 gene (042-type EAST1) (Figure 1). A subgroup of 7 aEPEC strains presented a variant type of the 042-type EAST1 gene sequence, with four non-synonymous nucleotide substitutions. Nine other strains, including one typical, carried either the sequence identical to type 1 SHEAST (7 strains) or to type 2 SHEAST (two strains). The remaining 13 strains carried mutated sequences of the 042-type EAST1 (five strains), type 1 SHEAST (two strains) or type 2 SHEAST (six strains) genes.

Table 1 EPEC-astA strains isolated from diarrheic and non-diarrheic children

\begin{tabular}{|c|c|c|c|c|}
\hline \multirow[t]{2}{*}{ EPEC } & \multirow[t]{2}{*}{ Serotype } & \multicolumn{3}{|c|}{ No. of strains (positive/total) } \\
\hline & & Diarrheic children & Non-diarrheic children & Total of children \\
\hline \multirow[t]{6}{*}{ tEPEC } & O55:NM;HND & $0 / 13$ & $0 / 1$ & $0 / 14$ \\
\hline & $\mathrm{O} 86: \mathrm{NM} ; \mathrm{H} 34$ & $0 / 2$ & 0 & $0 / 2$ \\
\hline & $\mathrm{O} 111: \mathrm{NM} ; \mathrm{H} 2, \mathrm{HND}$ & $4 / 9$ & 0 & $4 / 9$ \\
\hline & O119:NM;H6;HND & $2 / 22$ & $0 / 3$ & $2 / 25$ \\
\hline & O127:NM;H6 & $0 / 1$ & $2 / 3$ & $2 / 4$ \\
\hline & Other serotypes ${ }^{a}$ & $3 / 14$ & $0 / 2$ & $3 / 16$ \\
\hline Subtotal & & $9 / 61$ & $2 / 9$ & $11 / 70$ \\
\hline \multirow[t]{10}{*}{ aEPEC } & $\mathrm{O} 26: \mathrm{H} 11 ; \mathrm{HND}$ & $6 / 10$ & $0 / 2$ & $6 / 12$ \\
\hline & O55:HND & $2 / 3$ & $1 / 2$ & $3 / 5$ \\
\hline & O111:NM & $2 / 2$ & $1 / 2$ & $3 / 4$ \\
\hline & O114:NM & 0 & $0 / 1$ & $0 / 1$ \\
\hline & O119:H2;HND & $7 / 9$ & $0 / 3$ & $7 / 12$ \\
\hline & O126:NM & $0 / 1$ & 0 & $0 / 1$ \\
\hline & O127:NM;H40 & $0 / 3$ & $0 / 1$ & $0 / 4$ \\
\hline & O128:NM & $0 / 3$ & 0 & $0 / 3$ \\
\hline & $\mathrm{O} 142: \mathrm{NM} ; \mathrm{H} 2$ & $1 / 8$ & 0 & $1 / 8$ \\
\hline & Other serotypes ${ }^{\mathrm{b}}$ & $18 / 68$ & $5 / 34$ & $23 / 102$ \\
\hline Subtotal & & $36 / 107$ & $7 / 45$ & $43 / 152$ \\
\hline Total & & $45 / 168$ & $9 / 54$ & $54 / 222$ \\
\hline
\end{tabular}

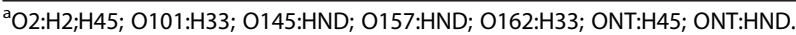

bO4:HND; O15:HND O33:H6; O35:H19; O37:HND; O49:HND; O61:HND; O63:HND; O79:HND; O85:H40; O96:HND; O98:HND; O101:NM; O103:NM; O105:H7; O108:H31; O109:H54; O117:HND; O132:HND; O141:HND; O1523H2; O156:H16; O157:HND; O167:H6; O169:H6; O175:HND;ONT:NM; ONT:H18; ONT:HND.

Note: NM, nommotile, ND, nondetermined, ONT, nontypeable. 


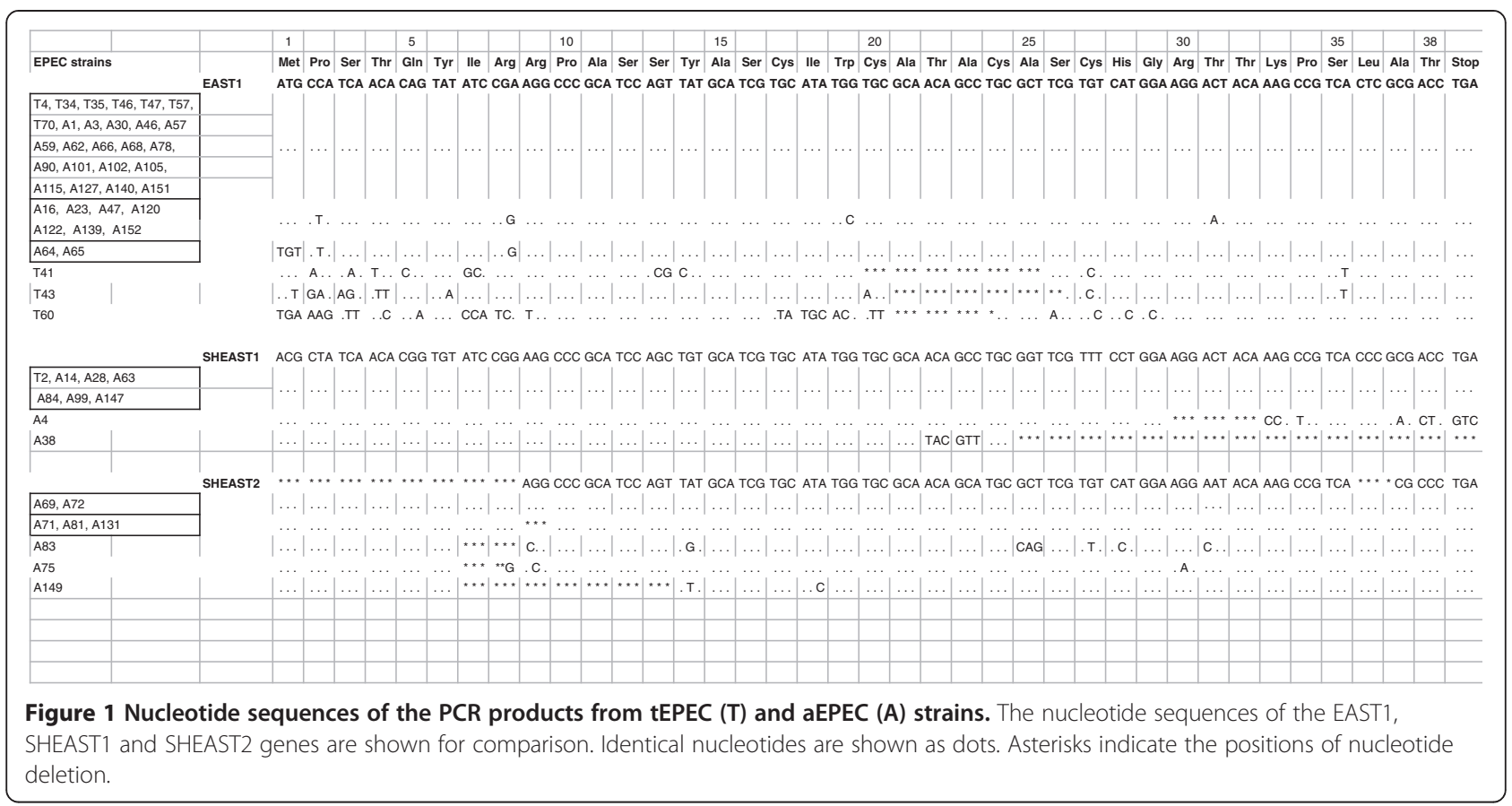

The expression of EAST1 was examined by RT-PCR and quantitative RT-PCR. The RT-PCR results showed that the astA gene was transcribed only by the strains carrying either the intact or the variant type of the ast $A$ gene sequence (Figure 2). The ast $A$ gene expression levels of the 32 RT-PCR positive strains (CT values ranged from $20.3 \pm 0.11$ to $21.6 \pm 0.04)$ were nearly identical to that of EAEC 042 strain (CT value $20.8 \pm 0.01$ ).

Plasmids of the 54 PCR-positive strains were examined for ast $A$ gene presence by Southern blot hybridization with the astA probe. In 23 (42.6\%) strains, a single copy of the astA gene was located to a large plasmid (Figure 3). In all the eleven tEPEC strains, the astA probe hybridized to the EAF plasmid as previously reported [21], and in twelve aEPEC the ast $A$ probe hybridized with large plasmids of similar size. The plasmids of the remaining strains were ast $A$ probe negative.

We previously reported that $24 \%$ of 65 aEPEC strains hybridized with a DNA probe for EAST1 [13]. Here, we analyzed by PCR a larger group of EPEC, including typical strains and found that 11 (16\%) of 70 tEPEC and 43 (28\%) of $152 \mathrm{aEPEC}$ were ast $A$ positive. Sequence analysis of the

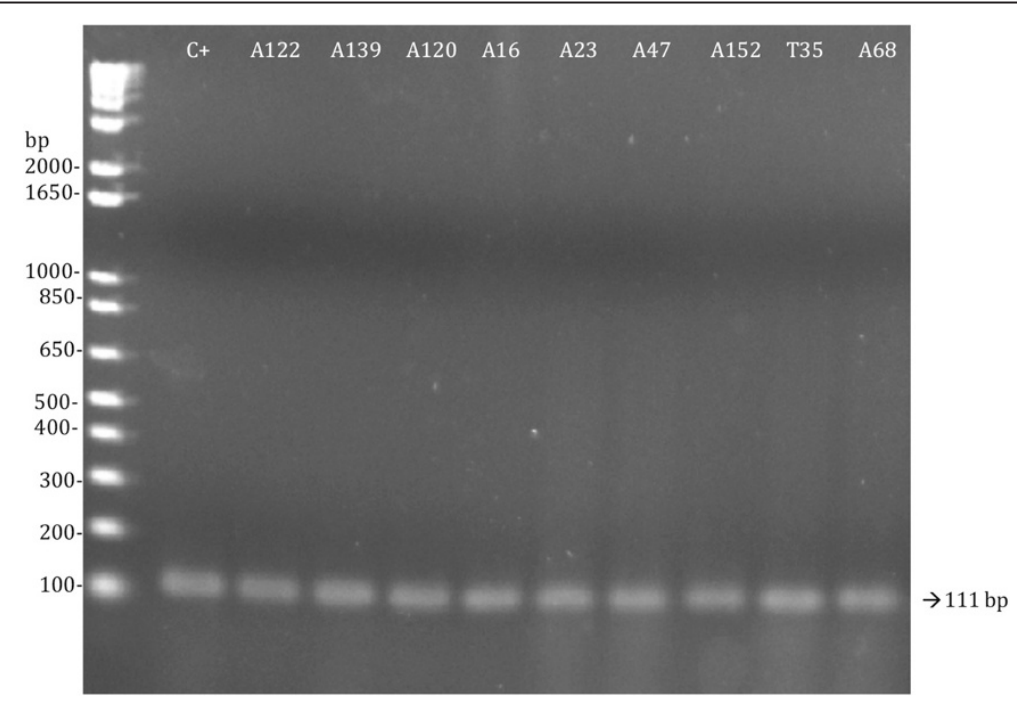

Figure 2 Agarose gel electrophoresis of the RT-PCR products of representative strains of tEPEC (T) and aEPEC (A). EAEC 042 strain $(C+)$ was used as positive control. Molecular size standard bands are at left. 


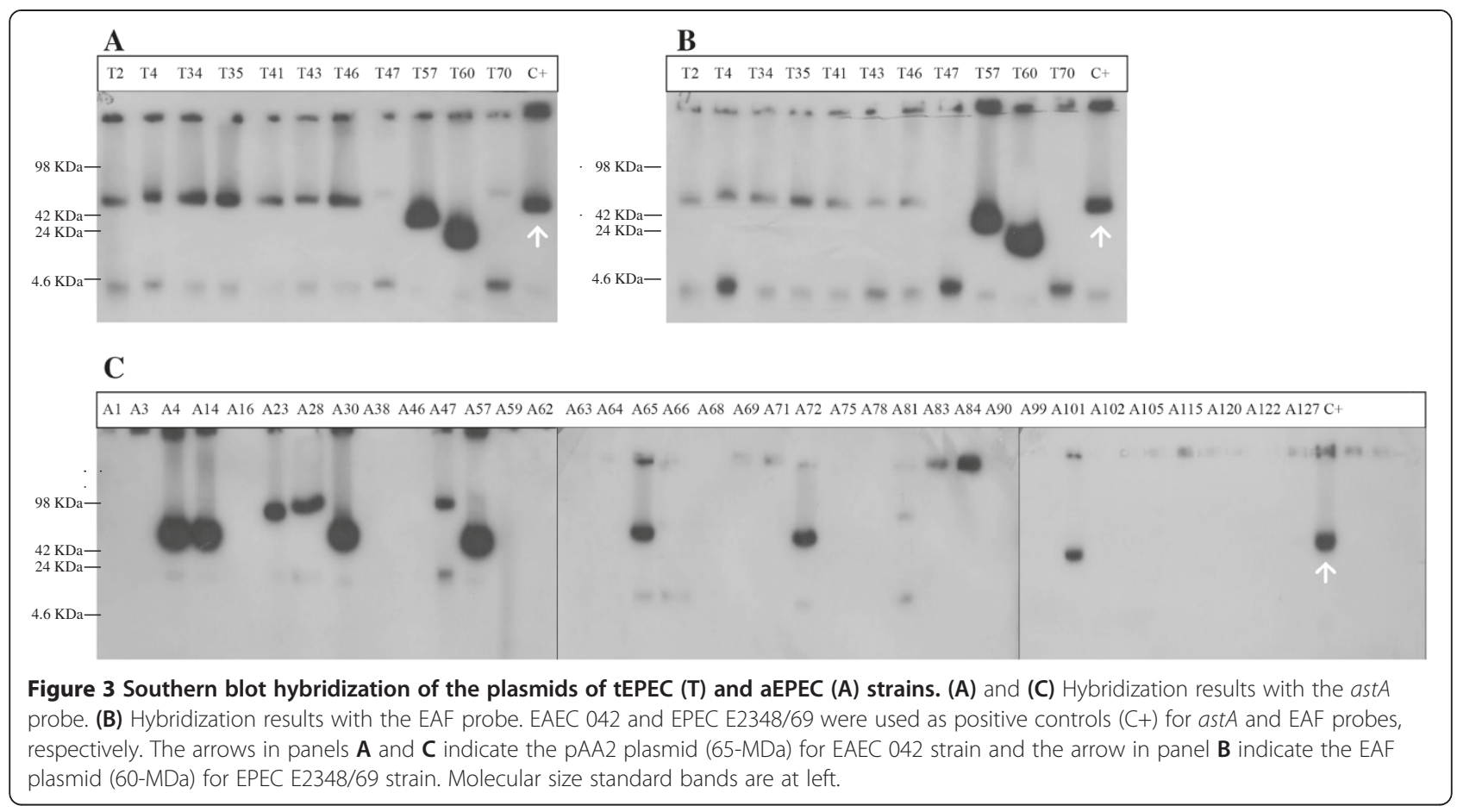

PCR products showed that 7 (63.6\%) of 11 tEPEC and 18 (41.9\%) of 43 aEPEC had an intact 042-type astA gene.

As shown in Table 2, strains carrying intact astA gene were more frequently found in diarrheic children than in non-diarrheic children $(\mathrm{p}=0.03$, Fisher's exact test). However, we should point out that among the 222 strains analyzed only 118 were collected from a casecontrol study [13].

The EAST1 gene family includes one major type of sequence, i.e. the ast $A$ of EAEC strain 042 that is widely distributed among different diarrheagenic E. coli strains [21-26] and four variant types of EAST1, i.e. the EAST1v1 of EAEC 17-2 [21,22], EAST1v2 of EPEC N1 [21], and EAST1v3 and EAST1v4 of E. coli O166:H15 [25].

In this study, a subgroup of aEPEC strains had a new variant type of EAST1 gene sequence that differed from those previously reported, and was denominated EAST1v5
(Figure 4). The RT-PCR analysis showed that EAST1v5 was transcribed to produce mRNA. However, more studies are necessary to determine whether EAST1v5 is associated with a functional polypeptide toxin.

\section{Conclusion}

In conclusion, our data suggest that the presence of an intact ast $A$ gene may represent an additional virulence determinant in both EPEC groups.

\section{Methods}

\section{Bacterial strains}

The 222 EPEC strains examined in this study included 176 strains isolated in 1999 to 2004 during an epidemiological study of acute diarrhea in children $<2$ years of age conducted in different regions of Brazil, and 46 strains isolated from children $<5$ years of age with diarrhea in

Table 2 Sequences of the ast $A$ gene found in EPEC strains isolated from diarrheic and non-diarrheic children

\begin{tabular}{|c|c|c|c|}
\hline \multirow{2}{*}{$\begin{array}{l}\text { ast } A \text { gene sequence } \\
\text { type }\end{array}$} & \multicolumn{2}{|c|}{$\mathrm{N}(\%)$ of strains from: } & \multirow[t]{2}{*}{ Serogroup $(n)$} \\
\hline & Diarrheic children & Non-diarrheic children & \\
\hline 042-type EAST1 & $24(14.3)$ & $1(1.8)^{\mathrm{a}}$ & $\begin{array}{l}\text { O9 (1), O33 (2), O108 (2), O111 (1), O119 (8), O142 (1), O152 (1), } \\
\text { O157 (1), O169 (1), OND (7) }\end{array}$ \\
\hline EAST1v5 & $6(3.6)$ & $1(1.8)$ & O26 (1), O9 (1), O96 (1) O111 (1), O141 (1), ONT (2) \\
\hline type 1 SHEAST & $6(3.6)$ & $1(1.8)$ & O26 (1), O55 (1), O103 (1), O153 (1), OND (3) \\
\hline type 2 SHEAST & $2(1.2)$ & 0 & $\mathrm{O} 26(1), \mathrm{O} 55(1)$ \\
\hline mutant & 7 & 6 & O26 (3), O55 (1), O111 (5), O119 (1), O127 (2), ONT (1) \\
\hline Total & 45 & 9 & \\
\hline
\end{tabular}

${ }^{a} p=0.03$; Fisher's exact test (diarrheic $x$ non-diarrheic). 


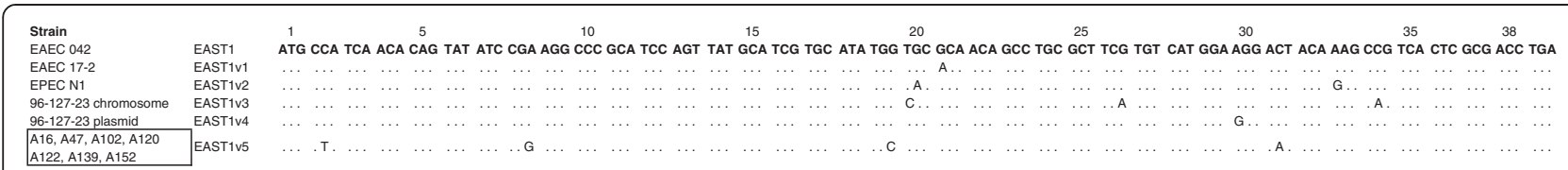

Figure 4 Nucleotide sequence of the EAST1 gene and its variants, including the new one described in this study. Identical nucleotides are shown as dots.

São Paulo between 2002 to 2003 [17-20]. All strains were characterized as tEPEC or aEPEC by hybridization with eae and EAF probes and serotyped (Table 1).

\section{Ethics statement}

The study was approved by the ethics committee of the Universidade Federal de São Paulo, Brazil. Stool samples were obtained with the written informed consent from the parents or guardians of the children.

\section{PCR assays}

For template DNA preparation, three to five isolated bacterial colonies grown on LB agar plates were pooled, suspended in $300 \mu \mathrm{l}$ of sterile distilled water, and boiled for $10 \mathrm{~min}$. PCR was carried out in a total volume of $25-\mu \mathrm{l}$ containing $5 \mu \mathrm{l}$ of template DNA. PCR primers were EAST13a (F-5'AGAACTGCTGGGTATGTGGCT) located 110 nucleotides upstream from the initiation ATG sequence of the astA gene, and EAST12b (R5'CTGCTGGCCTGCCTCTTCCGT) located 20 nucleotides downstream from the stop TGA sequence of the ast $A$ gene [26]. Cycling conditions were denaturation for $30 \mathrm{~s}$ at $95^{\circ} \mathrm{C}$, annealing for $120 \mathrm{~s}$ at $55^{\circ} \mathrm{C}$, and polymerization for $120 \mathrm{~s}$ at $72^{\circ} \mathrm{C}$ ( 30 cycles). PCR products were analyzed by $2 \%$ agarose gel electrophoresis.

\section{DNA hybridization}

The following probes were used in this study: astA, a 111-bp PCR product from EAEC 042 strain with the primer set EAST11a (5'-CCATCAACACAGTATTCCGA) and EAST12b (5'-GGTCGCGAGTGACGGCTTTGT) [26]; and EAF, a $1.0 \mathrm{~kb}$ BamHI-SalI fragment from plasmid pMAR2 [27]. The DNA fragments were purified, labeled with $\left[\alpha{ }^{32} \mathrm{P}\right] \mathrm{dCTP}$ with a DNA labeling kit (Amersham Pharmacia Biotech Inc., EUA) and used as probes. For Southern blotting, plasmid DNA was extracted using the method of Birnboim and Doly [28], separated in $0.8 \%$ agarose gel electrophoresis, and transferred to a nylon membrane, following a standard protocol [29]. Blots were hybridized in a solution containing the labeled probe $\left(10^{5} \mathrm{cpm}\right), 5 \times$ standard saline citrate (SSC), $2 \times$ Denhardt's solution (Invitrogen), $0.1 \%$ sodium dodecyl sulfate (SDS), and $5 \mathrm{mg} / \mathrm{ml}$ of salmon sperm DNA for $16 \mathrm{~h}$ at $65^{\circ} \mathrm{C}$. After hybridization, washes were done in aqueous solution with $2 \times$ SSC with $0.1 \%$ SDS and exposed to X-ray film.

\section{RNA extraction and RT-PCR assays}

Total RNA was extracted after bacterial growth in LB broth for $18 \mathrm{~h}$ at $37^{\circ} \mathrm{C}$ with the RNase Mini extraction kit (Qiagen) according to the manufacturer's instructions. After extraction, approximately $1 \mu \mathrm{g}$ of total RNA was digested with DNase I (Qiagen) for $30 \mathrm{~min}$ at $37^{\circ} \mathrm{C}$, and the enzyme was then inactivated by adding $1 \mu \mathrm{l}$ of $25 \mathrm{mM}$ EDTA and heating the solution at $65^{\circ} \mathrm{C}$ for 10 min. To obtain the cDNA, the SperScript III One Step RT-PCR System with Platinum Taq DNA polymerase (Invitrogen) was used according to the manufacturer's specifications. Primers for $16 \mathrm{~S}$ ribosomal protein were used to control PCR [30], and the assay was then carried out with the primers EAST11a and EAST11b [26]. PCR products were analyzed by $2 \%$ agarose gel electrophoresis.

Quantitative PCR was performed in a Mastercycler ep realplex ${ }^{4}$ (Eppendorf), and threshold cycle numbers were determined using Eppendorf realplex software (version 2.0). Reactions were performed in triplicate, and threshold cycle numbers were averaged. The 50- $\mu$ l reaction mixture was prepared as follows: $25 \mu \mathrm{l}$ of Platinum ${ }^{\circ}$ Quantitative PCR SuperMix-UDG (Invitrogen), $10 \mu \mathrm{M}$ of the Taqman probe (5'FAM-TGCATCGTGCATATG GTGCGCAA) and $10 \mu \mathrm{M}$ of each primer (R-5'GCG AGTGACGGCTTTGTAG and F-5'GAAGGCCCGCA TCCAGTT), and $10 \mu \mathrm{lof}$ cDNA (100 ng). The reaction consisted of: $2 \mathrm{~min}$ at $48^{\circ} \mathrm{C} ; 10 \mathrm{~min}$ at $95^{\circ} \mathrm{C}$ followed by 40 cycles of $15 \mathrm{~s}$ at $95^{\circ} \mathrm{C}, 1 \mathrm{~min}$ at $60^{\circ} \mathrm{C}$, and $1 \mathrm{~min}$ at $72^{\circ} \mathrm{C}$. The ast $A$ expression of the tested strains was compared to the astA expression of EAEC 042, according to the formula, $2^{(-\Delta \Delta \mathrm{Ct})}[31]$.

\section{DNA sequencing}

Nucleotide sequencing of the PCR products was performed at the Centro de Estudos do Genoma HumanoUSP, São Paulo. Nucleotide sequence data were analyzed using SeqMan and MegAlign software and the BLAST tool (http://www.ncbi.nlm.nih.gov/BLAST).

\section{Statistical analysis}

Data for diarrheic and non diarrheic children were compared using a 2-tailed Chi-square test. Results with $\mathrm{p}$ values $\leq 0.05$ were considered to be statistically significant. 


\section{Nucleotide sequence and accession number} The EAST1v5 gene sequence was deposited in the NCBI database under accession number KJ47188.

\section{Competing interests}

The authors declare that they have no competing interests.

\section{Authors' contributions}

LEPS and TBS performed experiments and analyzed data. NPS and ICAS wrote the manuscript. All authors read and approved the final manuscript.

\section{Acknowledgments}

This study was supported by research grants from Fundação de Amparo a Pesquisa do Estado de São Paulo (FAPESP) and Conselho Nacional de Desenvolvimento Científico e Tecnológico (CNPq). We thank Dr. Renata Torres de Souza for her help with the nucleotide sequence deposition.

\section{Author details}

'Departamento de Microbiologia, Imunologia e Parasitologia, Universidade Federal de São Paulo, Rua Botucatu, 862, 3 andar, 04023-062 São Paulo, Brazil. ²Disciplina de Reumatologia, Universidade Federal de São Paulo, São Paulo, Brazil.

Received: 29 January 2014 Accepted: 23 May 2014

Published: 30 May 2014

\section{References}

1. Ochoa TJ, Contreras CA: Enteropathogenic Escherichia coli infection in children. Curr Opin Infect Dis 2011, 24:478-483.

2. WHO: Programme for Control of Diarrhoeal Diseases, Manual for Laboratory Investigation of Acute Enteric Infections. Geneva: World Health Organization; 1987.

3. Nataro JP, Kaper JB: Diarrheagenic Escherichia coli. Clin Microbiol Rev 1998 11:142-201.

4. Moon HW, Whipp SC, Argenzio RA, Levine MM, Gianella RA: Attaching and effacing activities of rabbit and human enteropathogenic Escherichia coli in pig and rabbit intestines. Infect Immun 1983, 41:1340-1351.

5. Jerse AE, YU J, Tall BD, Kaper JB: A genetic locus of enteropathogenic Escherichia coli necessary for the production of attaching and effacing lesions on tissue culture cells. Proc Natl Acad Sci U S A 1990, 87:7839-7843.

6. Jarvis KG, Girón JA, Jerse AE, McDaniel TK, Donnenberg MS, Kaper JB: Enteropathogenic Escherichia coli contains a putative type III secretion system necessary for the export of proteins involved in attaching and effacing lesion formation. Proc Natl Acad Sci U S A 1995, 92:7996-8000.

7. Kenny B, DeVinney R, Stein M, Finlay BB: Enteropathogenic E. coli (EPEC) transfers its receptor for intimate adherence into mammalian cells. Cell 1997, 91:511-520.

8. Baldini MM, Kaper JB, Levine MM, Candy DC, Moon HW: Plasmid-mediated adhesion in enteropathogenic Escherichia coli. J Pediatr Gastroenterol Nutr 1983, 2:534-539.

9. Gómez-Duarte $\mathrm{OG}$, Kaper JB: A plasmid-encoded regulatory region activates chromosome eaeA expression in enteropathogenic Escherichia coli. Infect Immun 1995, 63:1767-1776.

10. Girón JA, Ho AS, Schoolnik GK: An inducible bundle-forming pilus of enteropathogenic Escherichia coli. Science 1991, 254:710-713.

11. Kaper JB: Defining EPEC. Rev Microbio/ São Paulo 1996, 27:130-133.

12. Trabulsi LR, Keller R, Gomes TAT: Typical and atypical Enteropathogenic Eschericia coli (EPEC). Emerg Infect Dis 2002, 8:508-513.

13. Dulguer MV, Fabricotti SH, Bando SY, Moreira-Filho CA, Fagundes-Neto U, Scaletsky ICA: Atypical enteropathogenic Escherichia coli strains: phenotypic and genetic profiling reveals a strong association between enteroaggregative $E$. coli heat-stable enterotoxin and diarrhea. J Infect Dis 2003, 188:1685-1694

14. Hedberg CW, Savarino SJ, Besser JB, Paulus CJ, Thelen VM, Myers LJ, Cameron DN, Barret TJ, Kaper JB, Osterholm MT: An outbreak of foodborne illness caused by Escherichia coli O39:NM, an agent not fitting into the existing scheme for classifying diarrheogenic E. coli. J Infect Dis 1997, 176:1625-1628.

15. Yatsuyanagi $Y$, Salto S, Miyajima T: Characterization of atypical enteropathogenic Escherichia coli strains harboring the astA gene that were associated with a waterborne outbreak of diarrhea in Japan. J Clin Microbiol 2003, 41:2033-2039.

16. Yamamoto T, Taneike I: The sequences of enterohemorrhagic Escherichia coli and Yersinia pestis that are homologous to the enteroaggregative E. coli heat-stable enterotoxin gene: cross-species transfer in evolution. FEBS Lett 2000, 472:22-26.

17. Scaletsky ICA, Fabbricotti SH, Aranda KR, Morais MB, Fagundes-Neto U: Comparison of DNA hybridization and PCR assays for detection of putative pathogenic enteroadherent Escherichia coli. J Clin Microbiol 2002, 40:1254-1258.

18. Scaletsky ICA, Fabbricotti SH, Silva SO, Morais MB, Fagundes-Neto U: HEp-2-adherent Escherichia coli strains associated with acute infantile diarrhea, São Paulo, Brazil. Emerg Infect Dis 2002, 8:855-858.

19. Araújo JM, Tabarelli GF, Aranda KR, Fabbricotti SH, Fagundes-Neto U Mendes CM, Scaletsky ICA: Typical enteroaggregative and atypical enteropathogenic types of Escherichia coli (EPEC) are the most prevalent diarrhea-associated pathotypes among Brazilian children. J Clin Microbiol 2007, 45:3396-3399.

20. Scaletsky ICA, Aranda KR, Souza TB, Silva NP, Morais MB: Evidence of pathogenic subgroups among atypical enteropathogenic Escherichia coli strains. J Clin Microbiol 2009, 47:3756-3759.

21. Yamamoto T, Wakisaka N, Sato F, Kato A: Comparison of the nucleotide sequence of enteroaggregative Escherichia coli heat-stable enterotoxin 1 genes among diarrhea-associated Escherichia coli. FEMS Microbiol Lett 1997, 147:89-96.

22. Savarino SJ, McVeigh A, Watson J, Cravioto A, Molina J, Echeverria P, Bhan MK, Levine MM, Fasano A: Enteroaggregative Escherichia coli heat-stable enterotoxin is not restricted to enteroaggregative $E$. coli. J Infect Dis 1996, 173:1019-1022.

23. Sousa CP, Dubreuil JD: Distribution and expression of the astA gene (EAST1 toxin) in Escherichia coli and Salmonella. Int J Med Microbiol 2001, 291:15-20.

24. Savarino SJ, Fasano A, Watson J, Martin BM, Levine MM, Guandalini S, Guerry P: Enteroaggregative Escherichia coli heat-stable enterotoxin 1 represents another subfamily of $E$. coli heat-stable toxin. Proc Natl Acad Sci U S A 1993, 90:3093-3097.

25. Zhou Z, Ogasawara J, Nishikawa Y, Seto Y, Helander A, Hase A, Iritani N, Nakamura H, Arikawa K, Kai A, Kamata Y, Hoshi H, Haruki K: An outbreak of gastroenteritis in Osaka, Japan due to Escherichia coli serogroup 0166: $\mathrm{H} 15$ that had a coding gene for enteroaggregative $E$. coli heat-stable enterotoxin 1 (EAST1). Epidemiol Infect 2001, 128:363-371.

26. Yamamoto T, Echeverria P: Detection of the enteroaggregative Escherichia coli heat- stable enterotoxin 1 gene sequences in enterotoxigenic $E$. coli strains pathogenic for humans. Infect Immun 1996, 64:1441-1445.

27. Nataro JP, Baldini MM, Kaper JB, Black RE, Bravo N, Levine MM: Detection of an adherence factor of enteropathogenic Escherichia coli with a DNA probe. J Infect Dis 1985, 152:560-565.

28. Birnboim HC, Doly J: A rapid alkaline extraction procedure for screening recombinant plasmid DNA. Nucleic Acids Res 1979, 247:1513-1523.

29. Sambrook J, Fritsch EF, Maniatis T: Molecular Cloning: A Laboratory Manual. 2nd edition. Cold Spring Harbor, NY: Cold Spring Harbor Laboratory Press; 1989.

30. Leverton $L Q$, Kaper JB: Temporal expression of enteropathogenic Escherichia coli virulence genes in an in vitro model of infection. Infect Immun 2005, 73:1034-1043.

31. Livak KJ, Schmittgen TD: Analysis of relative gene expression data using real-time quantitative PCR and the 2(-Delta Delta $C(T))$ method. Methods 2001, 25:402-408.

doi:10.1186/1471-2180-14-135

Cite this article as: Silva et al:: Detection and genetic analysis of the enteroaggregative Escherichia coli heat-stable enterotoxin (EAST1) gene in clinical isolates of enteropathogenic Escherichia coli (EPEC) strains. BMC Microbiology 2014 14:135. 